\title{
Regional Development Policy Through Housing Programs for Poor Communities in Pekanbaru City
}

\author{
Zaili Rusli ${ }^{1}$, Adianto ${ }^{2}$ \\ 1Public Administration Study Program Faculty of Social and Political Sciences, Riau University (email: \\ zailirusli.wdzr@yahoo.com), ${ }^{2}$ Public Administration Study Program \\ Faculty of Social and Political Sciences, Riau University (email: adianto@lecturer.unri.ac.id)
}

\begin{abstract}
Pekanbaru City as one of the cities in Indonesia that is experiencing rapid development and growth in the development of various fields. This reality shows that the City of Pekanbaru must be ready to face all forms of population problems that will arise, one of which is the housing needs of the urban poor. The purpose of this study is to comprehensively analyze regional development policies through housing programs for the community in Pekanbaru City. This type of research is qualitative research with a case study approach that uses key informants and supplementary informants as a source of information. Data collection is done through observation and interviews, then after the data collected will be used triangulation methods with data sources and then analyzed and interpreted by providing conclusions. The results of the study found that the form of housing policy for the people in Pekanbaru City consisted of the livable housing program (RLH), the city program and the house renovation program. Furthermore, the implementation of housing policy for the people in Pekanbaru City has run quite well. This means that every urban poor community is indeed a priority for the Pekanbaru City Government as a target group that must accept programs in the housing sector. However, the constraints of housing quota intended for the poor have not been able to fully meet the existing needs, so the Pekanbaru City Government has to make a turn system so that all urban poor communities can receive housing programs provided.
\end{abstract}

\section{Keywords:}

policies; housing programs; urban poor communities

\section{Introduction}

The city can be interpreted as a place with a denser population concentration than the surrounding area because of the concentration of functional activities related to the activities or activities of its population (Pontoh and Kustiwan, 2009). This understanding gives an understanding that the city will develop by the function of the area that has been determined to include urban settlements, centralization and distribution of government services, social services and economic activities. The development of the city must of course be done in a planned manner in an effort to improve and improve the standard of living of 
urban communities. So that in the future a prosperous, safe and peaceful urban community will be realized. But the development of the city will certainly have a positive impact and negative impact on the community. This happened, because of the development of the city already planned not under expected expectations. Therefore the problems that generally arise in the development and development of cities, including the problems of urbanization, urban poverty and the low quality of the environment.

Pekanbaru City as one of the cities in Indonesia that is experiencing rapid development and growth in the development of various fields, makes this city must be prepared to face all forms of risks that will arise. Because the city of Pekanbaru is also the capital of Riau Province which has a strategic location as a land transportation route for the island of Sumatra and also the city area which has a strategic position with neighboring countries, such as Malaysia and Singapore. The rapid development and growth of Pekanbaru City unwittingly had an impact on the high rate of urbanization. Pekenbaru City must be ready to face all forms of population problems that will arise, one of which is urban poverty. All forms of problems that arise in the city of Pekanbaru, must be responded to with the high commitment of the Pekanbaru City Government to overcome them. This commitment is shown by the strong vision and mission of the Pekanbaru City Government in overcoming all forms of problems that will arise.

One of the important mandates of the Pekanbaru City development mission is contained in the fourth mission which is to realize effective spatial planning and land use, and environmental preservation in realizing sustainable development. This means that the Pekanbaru City Government must be able to compile appropriate policies and programs to improve the realization of spatial planning and effective land use, and environmental preservation in realizing sustainable development, one of which is housing. Because the housing problem for poor people in Pekanbaru City is a complex problem. Because the housing assistance program for the poor that was implemented was still not on target. As a result there are still many urban poor who have not enjoyed the housing program for the poor that has been set by the government, both the Central Government and the Regional Government.

The success of a policy will largely depend on the implementation of the policy itself. Where, implementation involves the action of how far the programmed direction is really 
satisfying. Finally, at the highest level of abstraction implementation as a result there are some measurable changes in the major problems that the program targets. Ripley (1985) says implementation is a stage between policy making and the consequences of policy. Where he puts the implementation at the third stage in the policy process. The first stage of preparing the agenda, the second stage of policy formulation, the third stage of policy implementation and the fourth stage of the impact of the policy. He further asserted that successful implementation does not have only two perspectives: success is measured through the level of lower level bureaucratic adherence to top level bureaucracy and the success of implementation is sought by smooth routines and the absence of problems. While there are other perspectives that say that successful implementation leads to the desired performance of a program and the impact of the program.

Ripley and Franklin argue that implementation is what happens after laws are enacted that provide program authority, policy, benefits, or a real type of output. Ripley and Franklin emphasized that successful implementation does not have only two perspectives. First, success is measured through the level of bureaucratic compliance at the lower level of the upper-level bureaucracy. Second, successful implementation is characterized by smooth routines and the absence of problems. The success of a program can be seen if the program runs according to predetermined models. (Sujianto, 2008) Van Meter and Van Horn in Wahab (2012) formulate this implementation as actions taken either by individuals, officials or government or private groups aimed at achieving the objectives outlined in the policy decision. Van Meter and Van Horn's view that implementation is an act by an individual, official, group of government or private bodies directed at achieving the objectives outlined in a particular decision. Mazmanian and Sabatier in Leo Agustino (2008) explained that implementation is the implementation of basic policy decisions, usually in the form of laws, but can also take the form of important executive orders or decisions or judicial body decisions.

Typically, the decision identifies the problem to be addressed, states explicitly the goals / objectives to be achieved and various ways to structure / regulate the implementation process. This process takes place after going through a number of stages, usually beginning with the legalization stage, then outputs the policy in the form of implementing decisions by the implementing agency (agency), willingness to implement these decisions by the target 
groups, the real impact; whether desired or not from the output, the impact of the decision as perceived by the bodies that make the decision and finally important improvements (or efforts to make improvements) to the relevant law / regulation. Ripley (1985) says implementation is a stage between policymaking and the consequences of the policy. Where he puts the implementation at the third stage in the policy process. The first stage of preparing the agenda, the second stage of policy formulation, the third stage of policy implementation and the fourth stage of the impact of the policy. He further asserted that successful implementation does not have only two perspectives: success is measured through the level of lower level bureaucratic adherence to top-level bureaucracy and the success of implementation is sought by smooth routines and the absence of problems. While other perspectives say that successful implementation leads to the desired performance of a program and the impact of the program.

In different cases according to Erwan and Dyah Ratih (2012) implementation of policies can be a bridge, because it is through a delivery mechanism stage where when various policy outputs that are converted from policy input are conveyed to the target group as a concrete effort to achieve policy objectives. While according to Subarsono (2012) the policy that has been recommended to be chosen by policymakers is not a guarantee that the policy will certainly succeed in its implementation. Many variables that influence the successful implementation of policies, both individual and group or institutional. The implementation of a program involves the efforts of policymakers to influence the behavior of implementing bureaucrats to be willing to provide services and manage the behavior of the target group.

Policy implementation is the most severe, because here problems that are not found in the concept, arise in the field. Also Besides, the main threat is consistency in implementation. Approaches in the implementation of public policy by Peter deLeon and Linda deLeon in Riant Nugroho (2006) are grouped into three generations, namely:

a. The first generation, namely in the 1970s who understood the implementation of policies as problems that occurred between the policy and its execution. In this generation the implementation of policies coincides with the study of decision making in the public sector. This approach was used among others by Graham T. Allison with the Cuban missile case study $(1971,1979)$. 
b. The second generation, namely in the 1980s, is a generation that develops a policy implementation approach that is "from the top down" (top-downer perspective). This perspective focuses more on the task of the bureaucracy to carry out policies that have been decided politically. The social scientists who developed this approach were Daniel Mazmanian and Paul Sabatier (1983), and Paul Berman (1980). At the same time, a bottom-upper approach emerged, developed by Michael Lipsky $(1971,1980)$, and Benny Hjern $(1982,1983)$.

c. The third generation, namely in the 1990s, was developed by social scientist Malcolm L. Goggin (1990) who introduced the idea that the behavioral variables of the actors implementing policy implementation determine the success of policy implementation. At the same time, contingency or situational approaches to policy implementation emerge which suggest that policy implementation is largely supported by the adaptability of the implementation of the policy. The scientists who developed this approach include Richard Matland (1995), Helen Ingram (1990), and Denise Scheberle (1997).

Ripley and Franklin argue that implementation is what happens after laws are enacted that provide program authority, policy, benefits, or a real type of output. Ripley and Franklin emphasized that successful implementation does not have only two perspectives. First, success is measured through the level of bureaucratic compliance at the lower level of the upper-level bureaucracy. Second, successful implementation is characterized by smooth routines and the absence of problems. The success of a program can be seen if the program runs according to predetermined models. (Sujianto, 2008)

Then from some explanations it is concluded that the implementation of policy as a process of implementing policy decisions isusually in the form of laws, government regulations, regional regulations, and government programs. Where in this activity type of statement about the objectives to be achieved which are designed through concrete administrative activities, such as funding, planning, and organizing.

\section{Method}

This research uses qualitative research with a descriptive case study approach. To collect data and information, this research determines informants using a purposive 
sampling motive. Informants in this study: First, the key informants are people who know the research problem in depth. The key informants in this study are the regional development policy implementers in the housing sector, namely the Department of Public Housing and the City of Pekanbaru. Second, supplementary informants are people who are considered to know the research problem, even though the individual is not directly involved in the research problem. The complementary informants in this study are the people who accept the housing policy.

The data collection in this study was carried out by: (a) interviewing, which is the technique of extracting data and information in more depth, in an effort to comprehensively comprehend by means of direct question and answer addressed verbally to the respondent, which contains a number of main questions that have been prepared, with the aim to facilitate researchers in conducting interviews, because the questions have been structured so that they get results that are as expected. (b) observation is a technique to get data from the place of the observed research activity, but the researcher is not involved in the activity.

After the data collected from each research information, then the triangulation method will be used with a check and cross-check on the results of the response provided by research informants. One of the most important and easiest ways to test the validity of the research results is to triangulate. The triangulation technique used is triangulation with data sources. This method is done by comparing and checking both the degree of trust of information obtained through time and different ways. This type of qualitative research is descriptive, namely the problem-solving procedure that is investigated using describing data obtained from library observations and field observations, then analyzed and interpreted by giving conclusions. Qualitative research is a cyclical research process, which means simultaneous direct data collection and data analysis activities. For this reason, theoretical sensitivity is needed in the process of collecting data and analyzing data in the field, because it is the researcher himself who acts as the main instrument. By using a case study approach in qualitative research, researchers are expected to be able to present a picture or analysis result that is not only in the form of numbers, but a more in-depth description by the predetermined research focus. 


\section{Results and Discussion}

Urban development policy in the field of housing in Pekanbaru City is derived from Law Number 1 of 2011 concerning Housing and Settlement Areas as outlined in the Minister of Public Works and Public Housing Regulation Number 02 of 2016 concerning Quality Improvement of Slums and Slums and Regulations Minister of Public Works and Public Housing Number 07 of 2018 concerning Self-Help Housing Stimulant Assistance. These two forms of regulation serve as guidelines and guidelines for the Pekanbaru City Government in implementing urban development policy in the field of housing, especially for low economic communities. Because low-income people are people who have limited purchasing power, they need government support to get a decent home.

The process of implementing urban development policy in the housing sector in Pekanbaru City has been running from 2016 - 2018, both with the name of a habitable housing program or a self-help housing stimulant assistance program. The reality is that there are low-income people who have enjoyed urban development policy in the housing sector in Pekanbaru City, for more details, it can be seen in the table below:

Table 1.

The Frequency of Recipients of Urban Development Policy in the Field of Housing through the Livable Housing Program (RLH) or the Self-Help Housing Stimulant Assistance Program (BSPS) in Pekanbaru City

\begin{tabular}{|c|l|c|c|c|c|c|c|c|}
\hline No. & Program & \multirow{2}{*}{$\begin{array}{c}\text { Source of } \\
\text { funds }\end{array}$} & \multicolumn{4}{|c|}{ Planned Year } & \multicolumn{3}{c|}{ Year of Realization } \\
\cline { 4 - 9 } & & & $\begin{array}{c}2016 \\
\text { (RLH) }\end{array}$ & $\begin{array}{c}2017 \\
(\mathrm{RLH})\end{array}$ & $\begin{array}{c}2018 \\
(\mathrm{BSPS})\end{array}$ & $\begin{array}{c}2016 \\
(\mathrm{RLH})\end{array}$ & $\begin{array}{c}2017 \\
\text { (RLH) }\end{array}$ & $\begin{array}{c}2018 \\
\text { (BSPS) }\end{array}$ \\
\hline 1. & $\begin{array}{l}\text { Improving the } \\
\text { quality of the } \\
\text { house }\end{array}$ & DAK & - & 222 & 108 & - & 64 & 108 \\
\hline 2. & $\begin{array}{l}\text { Improving the } \\
\text { quality of the } \\
\text { house }\end{array}$ & APBN & 125 & 160 & 306 & 122 & 158 & 203 \\
\hline
\end{tabular}

Source: Department of Public Housing and Resettlement Area of Pekanbaru City, 2019

The table above explains that the urban development policy in the field of housing in the city of Pekanbaru through the program of livable houses (RLH) and the self-help housing stimulant program (BSPS) has been implemented from 2016 2018. Activities of urban area development policy in the field of housing are carried out by assisting in Improving the quality of houses owned by low-income people by applicable terms and 
criteria. Funding in urban development policy in the housing sector is supported through DAK and APBN funds. This fact explains the existence of a sharing budget in the context of implementing urban development policy in the field of housing in the city of Pekanbaru to meet the needs of housing for low-income people. This is despite the implementation that is still not fully targeted to reach low-income people. But the Pekanbaru City Government's commitment to implementing the policythe development of urban areas in the field of housing continues to run to meet the needs of shelter for its citizens.

Therefore, in an effort to evaluate the implementation of urban area development policies in the housing sector in Pekanbaru City, seen from the level of compliance and the smoothness of routine activities as follows:

\section{Level of compliance}

The level of compliance (compliance) is the compliance of the implementor in implementing the rules set by the organization. Compliance with the implementor rules and regulations that have been set in implementing the policy becomes important. Because with a high level of compliance, it is expected that the policies implemented will be successful. But on the contrary, if the level of compliance of policy implementers is low in implementing policies, then the failure will be obtained. Implementation of urban development policies in the field of housing in the city of Pekanbaru, seen from the suitability of the targets for the terms and criteria set.

Implementation of urban development policies in the field of housing in the city of Pekanbaru through the program of livable housing (RLH) and self-help housing stimulant program (BSPS), has the following criteria and conditions:

\section{a. Livable home program $(R L H)$}

Provision of assistance for the construction / repair of uninhabitable homes is provided to poor people who occupy / have uninhabitable homes with the aim of improving the quality of life / health status of the poor. The targets of this program are: 1). Poor people who live in houses that are not livable from the data collection of Pekanbaru City. 2). Uninhabitable houses that have not been registered in the results of the data collection determined by the Head of the local Kelurahan after obtaining consideration and the Implementation Committee for the Construction / Repair of Non-Livable Houses at the 
Kelurahan Level. Requirements for applying for assistance for the construction / repair of habitable houses (RLH), namely:

a) Request for assistance is submitted collectively by the Head of the Kelurahan.

b) Candidates for beneficiaries are prioritized in groups of houses / houses close together.

c) Requirements that must be fulfilled by prospective beneficiaries: ๑

- Residents in the local area as evidenced by a photocopy of KK and KTP Pekanbaru City.

- Submit a photocopy of the Proof of Land Ownership that has been validated by the Head of the local Kelurahan and or submit a Permit house construction / restoration if the land occupied is not their own.

d) Beneficiary criteria: ๑)

- Recipient Assistance for Rehabilitation of Livable Houses (RLH) must meet 3 (three) criteria, namely:

1. Home conditions The condition of the house is declared unfit for habitation, if it meets at least 2 (two) criteria in points (1), (2), and (3) and the following conditions:

a. Roof material in the form of leaves / thatch or roof tile that has been weathered / roof frame is weathered or zinc condition that has been damaged.

b. Floor material in the form of soil or stucco / tiles that have been damaged.

c. Wall materials in the form of poor quality bamboo / wood chambers or brittle / cracked brick walls, or permanent walls that have not been plastered.

d. Adequate solar lighting in the living room is less and $50 \%$ and in the bedroom less and $10 \%$.

e. Do not have bathroom and toilet facilities either inside or outside the house (communal) and do not have their own electricity connection.

2. Location and status of the house

a. The Prospective recipient's home is not included in the hostel owned by an agency. 
b. The house of the prospective recipient is not included as a house still in the period of bank credit.

c. House does not stand in the area of government bans, for example: river banks / embankments, reservoirs, village treasury land, cemeteries, sidewalks, road spaces.

d. Owned homes, not rented, not in dispute (eg land that has not been divided), do not stand on land owned by others (government foundations, companies, etc.). Owning land is evidenced by a photocopy of a land certificate or certificate of ownership of the land and the village / lurah head.

3. The owner of the house

a. Permanent domicile (resident) at the location of the activity and the house occupied by themselves; (Attachment Photocopy of KTP and KK (Family Card).

b. Willing to utilize social assistance that is done by self-help and work together.

c. Never received house renovation assistance in a row.

e) In fulfilling the reference criteria for prospective RLH recipients are: ๑)

- House conditions meet at least 2 (two) criteria at point 1 (roof), 2 (floor), and 3 (wall).

- Status and Location of Houses must meet all criteria.

- The house owner must meet all the criteria.

\section{b. Self-help housing stimulant assistance program (BSPS)}

Self-help Housing Stimulant Assistance, hereinafter abbreviated as BSPS, is Government assistance for low-income people to encourage and increase self-sufficiency in improving the quality of homes and the construction of new homes along with public infrastructure, facilities and utilities. The types of BSPS activities consist of:

1. PKRS (Improving the Quality of Self-Help Homes) is the activity of repairing uninhabitable houses into livable ones held on the initiative and efforts of the 
community, individually or in groups. PKRS activities to improve non-livable homes become habitable by fulfilling the following requirements:

a. Safety of buildings includes meeting reliability standards building structure components and improving the quality of building roofing, flooring and wall materials.

b. Occupant's health includes compliance with adequate standards lighting and ventilation facilities as well as the availability of building utilities including bathing, washing and toilet facilities.

c. Sufficient minimum building area includes fulfillment minimum space per person for building comfort.

2. PBRS (New Development of Self-Help Homes) is an activity for the construction of new, livable homes that is carried out above community initiatives and efforts, individually or in groups. PBRS activities are carried out by BSPS Recipients with the following requirements: a). the construction of new houses to replace completely damaged homes. b) construction of a new House on mature land plots.

BSPS recipients are low income people who meet the following requirements:

a) Indonesian citizens who are married.

b) Own or control the land based on legal rights.

c) Not owning a house, or owning and occupying the only house with unsuitable living conditions.

d) Have never obtained BSPS or government assistance for housing programs.

e) Earning the most as much as the provincial minimum wage.

f) Willing to be self-supporting and form a group of aid recipients (CDE) with joint responsibility statements

Implementation of urban development policy in the field of housing in the city of Pekanbaru through the program of livable housing (RLH) and self-help housing stimulant assistance program (BSPS), requires a level of compliance from the implementors. The level of compliance shown by the implementors is the key to success in the implementation process. Compliance that needs to be done by the implementor is to set policy targets by predetermined criteria and conditions. So that later low-income people will be able to truly 
benefit from the implementation of urban development policy in the field of housing in the city of Pekanbaru through the program of livable housing (RLH) and self-help housing stimulant assistance program (BSPS).

This research has conducted interviews with predetermined informants, one of them is the Head of Housing in the Department of Public Housing and Settlement Areas of Pekanbaru City regarding the level of compliance. The results of the interview are:

"We have implemented the housing policy program in compliance. Where we have given the program to low-income people here by predetermined criteria and conditions. Because this program helps the community in meeting their housing needs. " (Interview with the implementor 12 April 2019)

The same statement was also made by a different informant, namely the Head of the Data Collection and Planning Section of the House of Housing and the Housing Area of the City of Pekanbaru concerning the level of compliance. The results of the interview are:

"We have done the housing sector program according to the applicable regulations. Because if the community does not meet the established criteria and conditions, they will not accept the available programs. Because we are consistent with the rules that apply in implementing this housing sector program ". (Interview with the implementor 12 April 2019)

The results of this interview explained that the implementor was very compliant in implementing urban development policies in the field of housing in the city of Pekanbaru through the program of livable housing (RLH) and the self-help housing stimulant assistance program (BSPS). This level of compliance is shown by the consistency of the implementor with the criteria and requirements for each community as the target group. This means that people who do not meet the criteria and requirements set by the regulations, the implementor will not provide housing assistance programs to the community. This form of consistency is done so that the recipients of housing program assistance are truly low-income people in the city of Pekanbaru. So that this program does provide essential benefits to low-income people, especially in meeting the needs of their homes. 
The compliance of the implementor in the implementation process is carried out so that the quality of life of low-income people through housing and settlements that are healthy, safe, harmonious and orderly can be realized. Because the housing sector program has implemented activities to improve the quality of self-help homes and the construction of new self-help homes. Improving the quality of self-help homes is an activity to improve uninhabitable houses into livable ones which are carried out on the initiative and efforts of the community, individually or in groups. Where the improvement of the quality of selfhelp homes has building safety requirements, occupant health and minimum building area adequacy. While the new self-help housing construction activities are activities for the construction of new houses that are habitable for the community carried out on the initiative and efforts of the community, individually or in groups.

However, this study also crosses the response of the response from the community recipients of urban development policy programs in the field of housing in the city of Pekanbaru through the program of livable housing (RLH) and self-help housing stimulant assistance program (BSPS). The results of the interview are as follows:

"We as a community only accept this program, how do the government select it, we also do not know. Yes ... we are so given this program we are thankful ... but there are still some people here who are the same as us, not yet receiving the same assistance. So that sometimes there is an insinuation from some people about us ". (Interview with the recipient of the program 15 April 2019)

The same statement was also conveyed by the recipient community of other programs in the implementation of urban area development policies in the field of housing in the city of Pekanbaru through the program of livable houses (RLH) and self-help housing stimulant assistance programs (BSPS), as follows:

"We as a community only accept this program and do not have the authority to be involved in determining who has the right to receive it. As a result there are still the same communities as we have not received the program to date. Yes ... maybe it's because of the government's limited budget for this program. Sometimes there are still people who are better than us who also accept this program. We also do not understand why this is so ". (Interview with the recipient of the program April 16, 2019) 
The results of this interview explained that the level of compliance of the implementor in implementing urban development policy in the field of housing in the city of Pekanbaru through the program of livable housing (RLH) and the self-help housing stimulant assistance program (BSPS), is still not good. Because there are still people who are not included in the low-income category but accept this program. So that this reality raises jealousy from the people in the environment. Whereas in determining the prospective program recipients, the implementor has clear guidelines through the criteria and requirements of the target group. But in its implementation, there are still low-income people who have not yet received urban development policy in the field of housing in the city of Pekanbaru through the program of livable housing (RLH) and the self-help housing stimulant assistance program (BSPS). This fact could have been caused by government budget limitations in the implementation of urban development policy in the field of housing in the city of Pekanbaru through the program of livable housing (RLH) and the selfhelp housing stimulant assistance program (BSPS). Therefore, the implementor must be truly selective going forward in the process of implementing the program. So that in the future the implementation of this program will indeed be felt by the target groups that are by the established criteria and requirements.

Based on the results of interviews conducted about the level of compliance of the implementor in the implementation of urban development policy in the field of housing in the city of Pekanbaru through the program of livable housing (RLH) and the self-help housing stimulant assistance program (BSPS) concluded quite good. This means that in the implementation process, there were still program recipients who were following the established criteria and requirements, but there were also program recipients who did not comply with the applicable criteria and requirements. This reality must certainly be addressed by the implementor so that the program implementation can be carried out on target. Therefore, the level of compliance of the implementor becomes something important in the implementation process so that the program implemented has a high level of beneficiaries for low-income people in the city of Pekanbaru.

\section{Smoothness of Routine Activities}

The smoothness of routine procedures is the ability of the implementor to follow the rules set by the organization as a routine activity. Every public organization will certainly 
have the main tasks and functions carried out on daily and is a routine workload. Work assignments in the field of service to the public which would normally become routine work for employees daily. Because this work requires immediate handling and completion. Because if employees are not responsive in providing routine services to the public, it will cause dissatisfaction with public services and failure to implement routine tasks. Therefore, in expediting any routine tasks required employees who have the responsiveness and high responsiveness to public needs for routine services provided by the public institution. The responsiveness and responsiveness of employees must also be supported by their knowledge, expertise, and experience in serving the public.

The implementation of regional development policies in the housing sector in Pekanbaru City is fully carried out by the Department of Public Housing and Settlement Areas. The implementation of this policy is carried out through two programs, namely the livable housing (RLH) program and the self-help housing stimulant assistance program (BSPS). Therefore, in the implementation process there is a routine process or activity carried out by the Department of Public Housing and the City of Pekanbaru through the two programs, namely:

\section{a. Property housing program (RLH)}

Routine activities or processes carried out in the program of livable houses (RLH) by the Department of Public Housing and Settlement Areas have the following stages:

1. The organizing team submits data on the house to be rehabilitated to the Mayor by enclosing:
a. Photo the target house before repairing,
b. Fulfill the requirements in accordance with implementing instructions,
c. Make a statement about the readiness of the recipient community.

2. Verify the proposal for the data given by the Lurah to the Organizing Team.

3. The Organizing Team, accompanied by the Kelurahan, RW and RT, conduct explorations in the field to get a picture of the condition of the feasibility of the house so that the housing rehabilitation assistance program is on target.

4. The organizing team after verifying recommends to the Mayor to be determined by the Mayor's decision on the location and names of recipients of rehabilitation assistance for livable homes. 
5. Efforts to introduce or disseminate information about rehabilitation assistance for livable homes to the community as a target recipient of the program through a socialization program that targets are:
a. The target recipient community,
b. The Village consists of and RT / RW,
c. Community leaders.

6. The Material of socialization includes:

a. Patterns of work on housing rehabilitation assistance and environmental facilities

b. Rehab budget plan (RAB)

c. A Mechanism for proposing, disbursing and using rehab materials and implementing accountability

d. When Work Implementation

e. Report system

Decentralized Housing Development Program (RLH) in meeting the need for housing for poor or poor people. RLH development efforts are expected to be able to reduce poverty in the housing sector or where poor families live.

\section{b. Self-help housing stimulant assistance program (BSPS)}

Routine activities or processes carried out in the self-help housing stimulant assistance program (BSPS) by the Department of Public Housing and Settlement Areas, have the following stages:

\section{Proposed BSPS location}

The proposed BSPS location is addressed to the Minister c.q. Director General conducted by: a). regents / mayors with a copy of the governor; or b). Governor of the Special Capital Province of Jakarta. The proposed BSPS location includes the name of the village / kelurahan which is equipped with data on the number of uninhabitable houses and the number of self-supporting housing shortages. The proposed BSPS location carried out by the regent / mayor is verified by the provincial government. Provincial government in conducting verification based on:

- Poverty level in district / city area. 
- Proportion of the number of houses unfit for habitation to the number of houses in the district / city.

- Proportion of the number of House shortages to the number of households in the district / city area.

- Local government care in the housing sector.

- Central government priority programs

2. Determination of location

Based on the results of verification, the BSPS location is determined. BSPS locations for regency / city areas are determined by the Minister. The BSPS location for the village / kelurahan is determined by the Director General based on the BSPS location determined by the Minister.

3. Community preparation

Community preparation is carried out at the BSPS location. Community preparation is carried out through mentoring by field facilitators (TFL) to empower prospective recipient BSPS communities. TFL assits at stages, including:

a. The planning stage

The planning phase includes activities:

a) Socialization and / or counseling

b) Verification of prospective BSPS Recipients

c) Agreement on prospective BSPS Recipients

d) Identification of needs and preparation of proposals

The agreement of the BSPS Recipient candidates is carried out through the consultation of citizens to:

a) Determine the BSPS Recipient candidates

b) Form a group of aid recipients (CDE) and agree to joint responsibilities in implementing BSPS activities

c) Determine building material shops / providers

b. Stage of implementation

The implementation phase includes the activities of technical guidance in examining the number of building materials, building construction techniques, and building quality. 


\section{c. Stage of supervision}

The supervision phase includes monitoring the implementation of construction carried out among fellow members of the beneficiary group (CDE).

d. The reporting stage

The reporting phase includes technical guidance in compiling accountability report on BSPS activities.

e. Stage of independent development after the activity

The post-activity independent development phase includes technical guidance and supervision in the use, maintenance, and development of the results of BSPS activities.

4. Determination of BSPS Recipient candidates

Commitment-making officials (PPK) conduct examination of proposals submitted by prospective BSPS recipients. The results of the examination of the BSPS Recipient's proposals are determined by the PPK and approved by the KPA / Head of the Satker as the BSPS Recipient.

5. Disbursement, distribution and utilization of BSPS in the form of money

Disbursement of BSPS in the form of money is done through a channeling Bank/Post in accordance with statutory provisions. The distribution of BSPS in the form of money is carried out by the distributor Bank / Post to the BSPS Beneficiary account in 1 (one) stage. Utilization of BSPS in the form of money is carried out by the BSPS Recipient by way of transfer / transfer of money from the BSPS Recipient's account to the account store / building material provider for the purchase of building materials and cash withdrawals for payment of work wages.

6. Procurement and delivery of BSPS in the form of goods

Procurement of BSPS in the form of goods is carried out in accordance with the provisions of the legislation concerning procurement of government goods / services. Submission of BSPS form of goods carried out in accordance with statutory provisions. 


\section{7. $\quad$ Reporting}

BSPS recipients are accompanied by TFL in preparing and submitting accountability reports on the use of BSPS to PPK. The channeling Bank / Post submits accountability report on BSPS distribution to PPK. TFL submits reports to PPK through facilitator coordinator copy to the Office. The facilitator coordinator reports to the PPK carbon copy to the Dinas. PPK submits a report on the implementation of BSPS activities to KPA / Head of the Satker. KPA / Head of Satker submit BSPS activity reports to the Director General through the Director of Self-Help Homes.

This research has conducted interviews with predetermined informants, one of them is the Head of Housing in the Department of Public Housing and Settlement Areas of Pekanbaru City regarding the level of compliance. The results of the interview are:

"Recipients of livable housing (RLH) programs and self-help housing stimulant assistance programs (BSPS) that are intended for low-economic communities have basically coordinated with teams that have been determined to survey housing programs for communities that receive assistance. This effort is carried out so that the implementation of the program follows the laws and regulations that have been set ". (Interview with the implementor 14 April 2019)

The same statement was also conveyed by other implementors, namely the Head of the Data Collection and Planning Section of the House of Housing and Housing Areas in Pekanbaru City, as follows:

"The housing sector program in Pekanbaru City that we have implemented has followed the applicable rules, in accordance with the provisions contained in the regulations. We do not dare to carry out programs outside of applicable regulations, fearing the authorities and authorities will examine us ". (Interview with the implementor 14 April 2019)

This opinion is the same as that expressed by the recipients of the bantun program, namely low-income people in Pekanbaru City as follows:

"I see the provision of assistance in the field of housing programs through the program of habitable housing (RLH) and self-help housing stimulant assistance program (BSPS) conducted by the Department of Housing and Settlement Areas of the City of Pekanbaru is optimal. The government has tried its best to provide programs to the target groups who are 
truly entitled to receive them. Even if there is a recipient's error, it is very few percentages. Because the rules of the game in providing housing assistance programs are clearly regulated ". (Interview with program recipients on April 16, 2019).

The results of the interview above explain that the implementation of housing policy in the city of Pekanbaru that follows routine procedures in accordance with applicable regulations has been implemented by the implementor. The ability of an implementor to implement a program is inseparable from the level of the implementor's understanding of the program being run. The understanding possessed by the implementor is of course obtained by learning the technical instructions and implementation instructions from the program of livable houses (RLH) and the self-help housing stimulant assistance program (BSPS). The learning outcomes carried out turned out to provide understanding to the implementor to carry out housing programs in accordance with established routine procedures. Moreover, in the implementor there has been a fear of making mistakes or fraud in the process of implementing the housing sector policy. The fear possessed motivates the implementor to minimize errors and fraud in the implementation process.

The level of understanding possessed by the implementor provides a stimulus to be able to communicate the program of livable homes (RLH) and self-help housing stimulant assistance programs (BSPS) well to low-income people. The communication is carried out by the implementor to be able to provide socialization to low-income community parties to participate and participate in the housing sector program that is being carried out. Through the communication process carried out, the implementor will know and select low-income people who are eligible to receive housing assistance programs. The selection process for prospective recipients of the program must follow the routine procedures that apply. This is done so that the housing sector program that is carried out can be right on target and help low-income people in meeting their housing needs.

Based on the results of interviews conducted about the smoothness of routine procedures carried out by the implementor in the implementation of urban development policy in the field of housing in the city of Pekanbaru through the program of livable housing (RLH) and the self-help housing stimulant assistance program (BSPS), it was concluded to be good. This means that in the implementation process carried out by the implementor has followed the routine procedures set out by the legislation. This reality is 
inseparable from the level of understanding and communication skills possessed by the implementor in implementing housing programs to low income people. The ability to communicate and the level of understanding possessed by the implementor gives impetus to be able to carry out housing programs in the city of Pekanbaru in accordance with applicable rules and regulations. So that the recipients of housing policy programs are truly those who need and fulfill the requirements set by the legislation.

\section{Conclusion}

Urban development policy in the field of housing in the city of Pekanbaru through the program of livable housing (RLH) and the self-help housing stimulant assistance program (BSPS) has been running quite well. This means that the implementor has had a level of compliance in implementing a housing policy program for low-income people in the city of Pekanbaru. The level of compliance is indicated by the consistency of the implementor of the criteria and policy requirements set for the target group. In addition, the implementor is able to follow routine procedures set by the rules in the implementation process. The ability to follow routine procedures is demonstrated by understanding communication skills in the process of implementing housing policies in Pekanbaru City. To further maximize the implementation of urban development policy in the field of housing in the city of Pekanbaru through the program of livable housing (RLH) and self-help housing stimulant assistance program (BSPS), it needs a large and appropriate budget allocation. Because the number of low-income people in each region is different. So that this program will indeed be able to touch the entire target community in an effort to meet the need for shelter.

\section{References}

Anselm Strauss \& Juliet Corbin., 2007., Dasar-dasar Penelitian Kualitatif : Tatalangkah dan Tehnik-tehnik Teoritisasi Data., Pustaka Pelajar., Yogyakarta.

Bungin, Burhan., 2011., Metodologi Penelitian Kuantitatif., Kencana. Jakarta.

Charles O Jones., 1970., An Introduction to the Study of Public Policy., Belmont, CA : Wadswort.

Erwan Agus Purwanto dan Dyah Ratih Sulistyastuti., 2012., Implementasi Kebijakan : Konsep dan Aplikasinya di Indonesia., Penerbit Gava Media., Yogyakarta. 
Grindle Merike S., 1980., Policy Content and Context in Implementation Princeton., University Press., New Jersey.

James E. Anderson., 1979.," Public Policy Making"., Holt, Rinchard \& Winston., New York.

John W. Creswell., 2012., Research Design : Pendekatan Kualitatif, Kuantitatif dan Mixed., Pustaka Pelajar., Yogyakarta.

Kusumanegara Solahuddin., 2010., Model dan Aktor dalam Proses Kebijakan Publik., Penerbit Gava Media., Yogyakarta.

Mattew B. Miles and A. Michael Huberman., 1992., Analisis Data Kualitatif., UI - Press., Jakarta.

Moleong, Lexy J., 2007., Metodologi Penelitian Kualitatif., PT. Remaja Rosdakarya., Bandung.

Nugroho, Riant., 2004., Kebijakan Publik Formulasi, Implementasi dan Evaluasi., PT. Elek Media Komputindo., Jakarta.

Nugroho, Riant., 2014., Public Policy., Alex Media komputindo Gramedia., Jakarta.

Ripley Randel., 1985., Politic Analysis in Political Science., Neilson Hall., Chicago.

Solichin Abdul Wahab., 2012., Analisis Kebijakan Publik: Dari Formulasi ke Penyusunan Modelmodel Implementasi Kebijakan Publik., Bumi Aksara., Jakarta.

Subarsono A.G., 2012., Analisis Kebijakan Publik: Konsep, Teori dan Aplikasi., Penerbit Pustaka Pelajar., Yogyakarta.

Sujianto., 2008., Implementasi Kebijakan Publik., Penerbit Alaf Riau., Pekanbaru.

Tachjan., 2006., Implementasi Kebijakan Publik., AIPI., Bandung.

Tangkilisan Hassel Nogi., 2003., Evaluasi Kebijakan Publik, Penjelasan Analisis dan Transformasi Pikiran Nagel, Balairung \& Co., Yogyakarta.

Winarno Budi., 2012., Kebijakan Publik : Teori, Proses dan Studi Kasus., Pustaka Pelajar., Jakarta. 